\title{
Examining Operational Wastes within Greek Banking Operations
}

\author{
Dr Robert. A. Allen ${ }^{1} *$ \\ Giannis Panagoulis ${ }^{2}$ \\ Dr Gareth R.T. White ${ }^{3}$
}

Corresponding author*

\author{
${ }^{1}$ Cranfield University, Shrivenham. SN6 8LA \\ ${ }^{3}$ University of South Wales, Pontypridd. CF37 1DL
}

\begin{abstract}
In order to address operational effectiveness in the banking sector caused by the 2008 global economic crisis, this study examines the nature of operational wastes that exist within four large Greek banks. A Delphi study was undertaken with ten managers and ten employees. The waste of underutilised people is found to be the dominant form of waste present and affecting the efficiency of banking operations. This has implications for managers of banking operations needing to address efficiencies in an increasingly competitive global economic environment. The paper also highlights the drawbacks of analysing typologies of waste across organisations and industrial sectors.
\end{abstract}




\section{Introduction}

The 2008 global economic crisis was caused by a complex combination of rapid financial expansion, credit boom, increasing asset prices, and financial liberalisation and deregulation (Claessens and Kodres, 2014). Not only has this generated long-term economic uncertainty, bailouts (Kouretas and Vlamis, 2010) and a reshaping of financial institutions (HBA, 2017, p2), but it has led to a downfall in operational effectiveness across the banking sector. Argyrou and Kontonikas (2010) described the effect as being like a contagion that had spread across Europe. In a review of the overall banking efficiency in 25 EU countries for 20052006 (pre-crisis period) and 2009-2010 (post-crisis period), Alzubaidi and Bougheas (2012) concluded that there had been an average decrease in efficiency of $12 \%$. In the cases of Greece, Belgium and Denmark the decrease was even larger. For instance, among several such studies of efficiency within the Greek banking sector (Tsionas et al., 2003; Rezitis, 2006; Aggelopoulos et al. 2010; Alzubaidi and Bougheas, 2012), Varias and Sofianopoulou's (2012) study of the 19 biggest Greek commercial banks in 2009 found that that $68.42 \%$ of them were inefficient.

'Lean' tools and techniques have been the cornerstone of operational improvements for several decades (White and James, 2014; Syddell, 2005; Verstraete, 2004; Alavi, 2003; McCurry and McIvor, 2001; Mason-Jones et al., 2000) typically through the identification and elimination of non-value adding activities or 'waste' (Andersson, Eriksson and Torstensson, 2006). Many manufacturing industries have successfully adopted these techniques in order to improve operational efficiencies, including automotive, aerospace, information technology and electronics (Sohal and Egglestone, 1994; Doolen and Hacker, 2005; Tomas and Antonio, 2006; Wong et al, 2009; Neumann et al, 2012). However, their uses are not limited to the manufacturing sector and they have also been adopted in the public sector (White and Cicmil, 2015; Bateman, Hines and Davidson, 2014; Radnor and Walley, 2010), education (Emiliani, 2004), call centres (Piercy, Rich, 2009), healthcare (McCann, Hassard and Granter, 2015; McIntosh, Sheppy and Cohen, 2014; Esain, Williams and Massey, 2010), and, apposite to the context of this study, they have been employed in the financial services sector (Ndaita, Gachie and Kiveu, 2015; Leyer and Moormann, 2015; Delgado, Ferreira and Branco, 2010).

Recognising the current inefficiencies in the banking sector, particularly within Greece, and the importance of waste elimination to improve operational performance, this study examines the nature of operational wastes that exist within the banking function. This is achieved through a Delphi study of managers and employees of four large Greek bank. This is one of very few studies that examines the nature of operational waste within the service sector. The findings indicate that: Managers and employees consider the waste of underutilised people as having a significant influence on the efficiency of the banking sector. It is important to interpret studies of waste within a given organisational context as interorganisational and inter-sector comparisons are otherwise difficult to make. Whilst studies of typologies of waste are a useful, quantitative analytical methods may be more informative for managers wishing to address operational wastes.

The paper is structured as follows: firstly a review of the studies of waste is made. Following this the research methodology is detailed before the analysis and discussion are presented. It finishes with concluding statements and suggestions for future research.

\section{Literature Review}


Waste has been widely defined as the use of resources for any means other than the creation of value for a customer and is therefore a target for reduction and elimination throughout all operations (Womack et al., 1990; Liker, 1996; Hines and Rich, 1997; Russell and Taylor, 1999; Conner, 2001; Flinchbaugh, 2001; Rawabdeh 2005; Jimmerson et al, 2005). Canel et al., (2000, p. 51) proffer a useful working definition of waste as 'anything other than the minimum amount of equipment, materials, parts, space and worker's time, which are essential to add value to the product or service'.

Taichi Ohno (1988) is regarded as the father of the Toyota Production System, one of the most celebrated integrated systems for the continual improvement of manufacturing efficiency and effectiveness through the identification and reduction of waste. He categorized waste into seven types: defects, overproduction, inventory, over-processing, unnecessary motion, transportation (conveyance), and waiting.

Defects: refers to any product or service the customer is unwilling to accept (Gopinath and Freiheit, 2012). The crucial issue for a business is the identification of defects in order to take steps to then reduce or eliminate them. Undetected defects incur time and cost penalties. In a study of banking, Bicheno (2008) divided defects into two categories: internal and external failure. The former could be the wrong details being entered on a credit card or sums transferred to the wrong bank account; the latter a failure that invokes warranty, or repairs to software or hardware of bank system.

Overproduction: refers to making a product before a demand exists and which 'leads to excessive work in-progress stock which result in the physical dislocation of operations with consequent poorer communication' (Taylor and Brunt, 2001, p.28). Reducing or preventing overproduction through better alignment with demand, represents savings in terms of labour and material costs (Yu-Lee, 2011). Excluding defects, Sowards (2017) describes overproduction as 'the mother' of all other wastes.

Inventory: refers to any materials an organisation holds to satisfy internal or external customer demand (Mangan et al., 2012). The crucial characteristics of it rests on the strategic decisions regarding what to stock, how much to stock, and where to stock (Islam et al., 2012). Unnecessary inventory in the form of finished or semi-finished products or components creates waste from storage costs and limits business competitiveness (Bicheno, 2008; Damrath, 2012).

Overprocessing refers to redundant effort and unnecessary extra steps (Ortiz, 2009) that leads to undertaking more fabrication or assembly line work than is necessary to meet customer needs (Yu-Le, 2011). Overprocessing can be unnecessary reviews or requests for signatures or activities that leads to additional consumption of parts and raw materials per unit of production, increased waste, energy usage, and emissions (Hallam and Contreras, 2016). An increase of flow lengths and bottlenecks that affect the efficiency of operations (Bicheno and Hines, 2004).

Motion: can refer to both human activity and organisational layout and is the unnecessary movement of people and equipment often derived from poor workplace organisation (Sullivan et al., 2002). Detailing the specifics of motion associated with waste Okpala (2014) suggests that any bending, lifting, stretching and kneeling that is not undertaken without reference to the application of ergonomics can represent not only a monetary and equipment cost (from wear) but an unnecessary stress on personnel. Through addressing and monitoring 
movement, managers and employees can identify needless activity and better utilise their time to serve more customers (Womack, Jones and Ross, 1990).

Transportation (Conveyance): is a necessary element of business operations; however, the transfer of materials, components, work in progress or finished products from places of work, warehouses or suppliers between processes does not add value (Chomatowska and Żarczyńska- Dobiesz, 2014). Moving products more than is required slows output, consumes labour and can consume finite equipment capacity (Yu-Lee, 2011)

Waiting: refers to any resources or material staying idle during working hours (Gopinath and Freiheit, 2009). Waiting reduces customer satisfaction and increases time, quality, productivity and operations cost (Womack and Jones, 2003). From a customer point of view, waiting is boring, frustrating and irritating (Hui and Tse 1996; Katz et al., 1991) and represents a major factor in customer satisfaction and business competitiveness (Bicheno, 2008). The perception of the service can be affected by aspects such as waiting time and the length of queues and can generate a negative view of the organisation that ultimately causes the loss of consumers (Taylor, 1994; Hui and Tse, 1996; Bielen and Demoulin, 2007). Frustration caused by waiting is not restricted to face-to-face encounters, Demoulin and Djelassi (2013) note that slow online banking systems can have a similar effect on evaluation of service.

It can be seen that the majority of research around waste identification and elimination has emanated from the manufacturing sector. Typically, it is seen to add cost in the form of inventory, set-up, scrap and rework (Svenssen, 2001) while Wojakowski and Warzolek (2017) noted that $60 \%$ of waste is generated by waiting, over processing and motion. Wood (2004) however, warns that businesses have traditionally concentrated on improving labour productivity but that in a typical process $95 \%$ of the day-to-day activities are non-value adding and therefore represent a greater proportion of total work that requires examination.

Much of the research into operational waste has been influenced by Ohno's seminal typology (see Table 1). These examinations of the seven wastes indicate that there are differences in the occurrences of wastes between primary and secondary manufacturing sectors (for example Esain, 2000 and Rawabdeh, 2005) and between service and manufacturing sectors (for example Esain, Griffiths and Hines, 2001 and Goriwondo, Mhlanga and Marecha, 2011). El-Namrouty and AbuShaaban's (2013) work even indicates that there can be differences within geographical regions. Collectively they point toward the importance of examining the prevalence of wastes within specific circumstances and the usefulness of Ohno's categorization of the seven types of waste in framing such an examination.

Insert table 1 Here

\section{Methodology}

In order to examine the types of waste that exist within Greek banking operations this research employs a Delphi study (Kosow and Gassner, 2008; Skulmoski, et al., 2007; Linstone and Turoff, 197; Dalkey and Helmer, 1963). The Delphi technique pioneered by Helmer and Dalkey in the 1950s generally uses a group of people who have a stake or interest in the research idea to generate and choose a more defined research idea (Robson, 2002).

The technique has been used in studies across a wide variety of sectors including cryptocurrency (White, 2017), business improvement (Harer, 2003; Ray and Sahu, 1989), employee and public relations (Watson, 2008; Wiggington, 1979), knowledge management 
(Scholl, et al., 2004), marketing (Knutson, et al, 2004; Larreche and Montgomerey, 1977), productivity management (Ray and Sahu, 1990), project management (Brill, et al., 2006), supply chain management (Melnyk, et al., 2009; Lummus, et al., 2005), tourism (Muller, 2005; Yong, Keng and Leng, 1988), social enterprise (White et al., 2017) and information systems (Hong, et al., 2015; Huang, et al., 2013; Liu, et al., 2010; Bradley and Stewart, 2003; Kell, et al., 2002; Schmidt, et al., 2001; Koskiala and Huhtanen, 1989).

It is an effective technique for combining deductive and inductive approaches to make robust investigations into complex phenomena (Kosow and Gassner, 2008; Petry, 2007; Skulmoski, 2007; Yin, 2003; Rowe and Wright, 1999; de Vos, 1998; Mitchell, 1992; Paliwoda, 1983; Jick, 1979). However, it does present practical challenges that comprise the selection of suitable participants, retaining participant commitment and the utilisation of appropriate analytical instruments (Makkonen, et al., 2016; Gary and von der Gracht, 2015; Okoli and Pawlowski, 2004; Wentholt and Frewer, 2010; Brill, et al., 2006; Paliwoda, 1983).

The approach taken in this study comprises a two-round study, incorporating descriptive statistics and Kendall's W measure of concordance (Gary and von der Gracht, 2015; Boulkedid et al., 2011; Wentholt and Frewer, 2010; Watson, 2008; Petry, et al., 2007; Okoli and Pawlowski, 2004; Scholl, et al., 2004; Harer, 2003). Kendall's W has been widely used in many Delphi studies including cryptocurrency (White, 2017), construction (Idrus and Newman, 2002), education (Manalo, 2013), human resource management (Papavasileiou and Lyons, 2015), information system development (Shang, 2012), performance management (Rashvand and Majid, 2014), retailing (Rupesh and Narayanan, 2016), risk management (Bessette, Campbell-Arvai and Arvai, 2016) and social enterprise (White et al., 2017). Values of Kendall's W range between 0 (no agreement) and 1 (complete agreement). The interpretation of intermediate measures of $\mathrm{W}$ remain moot, some considering values over 0.63 to be moderate degrees of concordance (Hays, 1998) while others consider values of between 0.5 and 0.7 indicate moderate concordance (Schmidt, 1997). When measures of concordance are employed, it is more appropriate to utilise them as inter-round comparators rather than absolute measures since it is not necessarily the purpose of Delphi studies to attempt to reach consensus (Engelke, Mauksch, Darkow and von der Gracht, 2016).

The Delphi panel consisted of ten managers and ten employees (see Table 2 for participant details) of four large Greek banks (see Table 3 for bank details). In order to protect the identities of the participants and the banks within which they work, the specific details of each have been changed (participants are coded ' $M$ ' for Managers and ' $E$ ' for Employees and numbered 1 to 10). To further protect confidentiality all figures have been approximated. Table 2 outlines the demographic profile of the participants and the banks.

Typical response rates in research vary between 3\% and 50\% (Ranchord and Zhou, 2001). The face-to-face distribution and collection of the survey instrument resulted in $100 \%$ participation across both rounds (Collis and Hussey, 2009). Participants were asked to rank the seven wastes that occurred in banking operations in order of importance. In order to improve the validity of Delphi studies they may be combined with qualitative data capturing methods (Engelke, et al., 2016; de Vos, 2005; Rowe and Wright, 1999). This study employed interviews with managers of each of the four banks between Round 1 and Round 2 in order to gain a richer insight into the banking operations and the types of waste that are typically encountered (Denscombe, 2010; Fox, 2009). This data was used to refine the Delphi survey 
and participants were asked to re-rank the types of waste that occurred in banking operations in Round 2.

\author{
Insert Table 2 Here
}

The mean age of the sample is 46.5 and the length of service is 21.55 years, which suggests a high level of experience related to the operation of banking systems and customer interaction amongst the sample. Greek banks have historically employed more males than females, especially in management positions and so the split between the genders in the sample is not unusual.

\title{
Insert Table 3 Here
}

\section{ANALYSIS and DISCUSSION}

In Round 1 the Employees returned a very low degree of concordance $(\mathrm{W}=0.129)$ in their assessment of the order of importance of the seven forms of waste. The Managers returned a similarly low degree of concordance $(\mathrm{W}=0.198)$ in their interpretation. Overall, the combined rankings of the Employees and Managers returned $\mathrm{W}=0.127$.

Table 4 presents the relative order of importance of each of the wastes in Round 1, as perceived by the Employees group, the Managers group, and their combined rankings. It is interesting to note the marked difference in the Employees' and Managers' appreciation of the importance of Overproduction and Inventory. The Employees regarded Overproduction as a minor issue, but Inventory as a significant problem, whereas the Managers consider Inventory to be insignificant but Overproduction to be their second most important concern. This is curious since both of these forms of waste are highly interrelated: Overproduction leads to an increase in Inventory.

\section{Insert Table 4 Here}

After the first-round questionnaires were collected, two of the ten managers noted that the efficiency of banking operations relies on how the bank appoints the right person in a position. Some literature has examined non-value adding activities in other sectors and discovered further forms of waste. Womack and Jones (1996) for instance add an eighth waste of 'making the wrong product efficiently'. To this, Bicheno and Hines (2004) add a further three comprising the waste of untapped human potential, the waste of inappropriate systems and the waste of energy and resources. Untapped human potential refers to those talented employees who possess a high degree of experience or skills but who do not give fully to the organisation due to a lack of commitment because of miscommunication amongst workers, or because they have been placed in a suboptimal position within the organisation (Johnston, 2008). An inappropriate system refers to those such as MRP or ERP, which may cause problems with service flow, for example generating extra paperwork, which increases costs through unnecessary motion (George, 2003). In recognition of this, the eighth waste of 'Unutilized People' was added in the second-round questionnaires.

In Round 2 the Employees returned a higher degree of concordance $(\mathrm{W}=0.32)$ than that returned in Round 1 (W=0.129). Similarly, the Managers also demonstrated a higher degree of concordance $(\mathrm{W}=0.37)$ than in Round $1(\mathrm{~W}=0.198)$. The overall degree of concordance was also considerably higher $(\mathrm{W}=0.3)$.

Table 5 presents the relative order of importance of each of the wastes in Round 2, as perceived by each individual group and their combined rankings. It is most interesting to note the greater similarity in each group's perceptions of the relative importance of each form of 
waste: as an increased measure of concordance would suggest. However, what is not indicated by the mere comparison of measures of $\mathrm{W}$ is the nature of the changes that have taken place. It is significant that the Employees' appreciation of the relative importance of each of the wastes has changed very little between rounds whereas the Managers' relative rankings have changed considerably: in particular, the perceptions of the significance of Overproduction and Inventory are more in accord.

It is also encouraging to note that in Round 2 both Employees and Managers recognised Underutilized Resources as a significant source of waste that exists, however, it is correspondingly disappointing to note that all staff appreciate that their own talent is not leveraged to its maximum capability. Under considerable pressure to reduce spending on operations and offer the customer greater value for money it falls to those who manage the banking system to seek to reduce instances of waste and a direct and effective way of doing this is to concentrate efforts on making sure that the personnel employed by the bank are effectively utilized.

\section{Insert Table 5 Here}

Inspection of the individual responses indicates that participant E6's rankings changed considerably between rounds. Indeed, the sum total of their rankings for each of the wastes changed by 11 points. In comparison, the other Employees' rankings changed between 0 and 6 points between rounds. Kendall's W for Round 1 and eliminating the rankings provided by participant E6, returns $\mathrm{W}=0.17$. This suggests that E6's responses are somewhat anomalous in Round 1 (compared to the rest of the participant group). However, a similar analysis of Round 2 results, removing the responses for E6, does not produce a comparable change in Kendall's W (with E6 W=0.324, without E6 W=0.327) and this indicates that E6's results are harmonious with the remainder of the group in Round 2.

Similar inspection of the variance in the Managers' rankings between rounds indicates that their rankings changed considerably. The minimum change in rankings was 5 points (for participants M2 and M7), whereas M1 changed their rankings by the most (10 points), and participants M9, M10 and M5 each changed their rankings by 9 points. It is this considerable shift in appreciation of the importance of each of the wastes that results in their views becoming more aligned with those of the Employees in Round 2 of the study. This is important as firstly it (problematically) suggests that there is a tacit difference between Employees' and Managers' understanding of the types of wastes that are prevalent, and secondly it (constructively) indicates that Managers' perceptions are highly fluid and subject to change upon reflection.

In the absence of any other studies that make an examination of the forms of waste that are present within the banking sector it is necessary to make comparison to those studies that have been undertaken in other industries and sectors (Table 1). Generally, the managers and employees of Greek banks highlighted the issues of defects, overproduction and waiting, and this broadly reflects the situation in other sectors. There are some exceptions, for instance, overproduction, as one would expect, is not a pertinent issue in a job-shop where production is not arranged around batched work, similarly, bread manufacturing may be arranged upon a continuous process and therefore not be subject to problems of overproduction. Interestingly, in the only other examination of a service industry (procurement services), the perception of the importance of the waste of defects differs markedly. Making a critique of this difference is impossible without detailed knowledge of the systems of work that are employed: the procurement services function may for instance employ automated electronic procurement as part of an enterprise-wide management information system, in which case the chance of 
defects arising may be negligible (Chaffey and White, 2011). It must also be considered that unlike procurement, banking operations are customer-facing. Simple acts such as the entry of wrong data or payment to the wrong vendor have great impact in by undermining customer satisfaction and in some circumstances can lead to Government intervention, reference to an ombudsman and subjection to audit. It is not unreasonable then that managers and employees should highlight the importance of defects against a background such measures and during a time when national and international competition for banking services is high.

\section{Conclusion}

While some studies have examined the overall efficiency of the Greek banking sector, to date, none have explored the nature of the inefficiencies that manifest as waste. This study addresses this by undertaking a Delphi study of manager and employee perceptions of operational waste within several large Greek banks. This research was undertaken at a time when the Greek banking sector was taking great steps to present a more efficient and effective service to both their international and national customers and to provide reassurance that they had addressed many of the criticism that had been raised by those such as the IMF and the World Bank. This study has highlighted that managers and employees consider the waste of unutilized people as having a significant impact on the efficiency of banking sector, something that has rarely been noticed in other industries.

Many studies of waste have adopted the 'classical' seven wastes that were originally proposed by Taichi Ohno. While these are useful aids for the identification of operational inefficiencies their application is more difficult in service environments. Future work could attempt to develop service-based definitions and descriptions of each of the types of waste. In addition, future studies of waste, and practical initiatives to examine operational inefficiency by practicing managers, should be mindful of the extended typologies of waste that exist, in particular those that comprise that of 'underutilized resources' in order to ensure that this important and most valuable asset is not neglected.

This study indicates that it is imperative to fully understand the operational context of the research site in order to successfully interpret the results. For instance, the rank order of the importance of wastes in Greek banks closely resembles those found in some manufacturing environments but varies from those found in service environments where it may be assumed that there would be a greater degree of commonality. This raises questions over the comparability of analyses of wastes between sectors and even between different parts of a single organisation. This has practical implications for managers that are attempting to benchmark their performance both inter- and intra-sector. We proffer that this highlights the importance of the fundamental message of lean that is 'continual improvement'. While analyses of types of waste may be useful indicators of the nature of the operational inefficiencies that require attention, quantitative measurements of wastes through techniques such as process mapping may be more valuable in allowing comparative analyses between sectors and the objective assessment of the effectiveness of intervention strategies (White and Cicmil, 2016; White and James, 2014).

The generalisability of this study's findings is limited by the relatively small sample size that is necessary to practicably operationalise the Delphi method. However, the results are based upon data from four of the largest Greek banks and therefore can be said to have reached meaningful conclusions. Future research could adopt survey instruments in order to garner results from a larger sample. 


\section{References}

Alavi, S. (2003), "Leaning the right way”, Manufacturing Engineer, Vol. 82 No. 3, pp. 32-35. Alzubaidi, H. and Bougheas, S. (2012), 'The impact of the global financial crisis on European Banking Efficiency', Centre For Finance and Credit Markets.

Andersson, R., Eriksson, H. \& Torstensson, H. (2006). Similarities and differences between TQM, six sigma and lean. The TQM Magazine, 18(3), 282-296.

Argyrou, Michael G., and Alexandros Kontonikas. 2010. "The EMU Sovereign-Debt Crisis: Fundamentals, Expectations and Contagion." Cardiff Business School Working Paper E2010/9.

Bateman, N., Hines, P., Davidson, P. (2014) Wider Applications for Lean: an examination of the fundamental principles within public sector organisations. International Journal of Productivity and Performance Management, 63(5), 550-568.

Bessette, D.L., Campbell-Arvai, V., Arai, J. (2016), "Expanding the Reach of Participatory Risk Management: testing an online decision-aiding framework for informing internally consistent choices." Risk Analysis, Vol 36 No 5, pp 992-1005.

BeyondLean (2011), "Value stream mapping", available at: www.beyondlean.com/valuestreammapping.html (accessed November 2017).

Bicheno, J. (2008) The Lean Toolbox for service systems. United Kingdom: Picsie Books, United Kingdom.

Bicheno, J. and Hines, P. (2004) The new Lean Toolbox: Towards fast, flexible flow. $3^{\text {rd }}$ edn. Buckingham, England: Production and Inventory Control, Systems and Industrial Engineering Books.

Bielen,F and Demoulin, N. (2007) "Waiting time influence on the satisfaction-loyalty relationship in services", Managing Service Quality: An International Journal, Vol. 17 Issue: 2, pp.174-193

Boulkedid , R., Abdoul, H., Loustau, M., Sibony, O., and Alberti, C. (2011), Using and Reporting the Delphi Method for Selecting Healthcare Quality Indicators: A Systematic Review. PLos One,

Bradley L., and Stewart K. (2003), "A Delphi Study of Internet Banking”. Marketing Intelligence and Planning, Vol 21 No 4/5, pp. 272-281.

Brill J.M., Bishop M.J., and Walker, A, E. (2006), "The Competencies and Characteristics of an Effective Project Manager: A Web-Based Delphi Study", Educational Technology, Research and Development, Vol 54 No 2, pp.115-140.

Canel, C., Rosen, D. and Anderson, E.A. (2000), "Just-in-time is not just for manufacturing: a service perspective", Industrial Management \& Data Systems, Vol. 100 No. 2, pp. 1-60.

Chaffey, D. and White, G.R.T. (2011) Business Information Management, second edition. Pearson Education: UK.

Chen J., and Cox, R. (2012) "Value Stream Management for Lean Office-A Case

Study," American Journal of Industrial and Business Management, Vol. 2 No. 2, 2012, pp. 17-29. 
Chomątowska B. \& Żarczyńska-Dobiesz A., (2014), Elimination of waste in production enterprises - case studies, Research in Logistic \& Production, Vol. 4, No. 2, pp. 157-166.

Claessens, S and Kodres, L (2014). The Regulatory Responses to the Global Financial Crisis: Some Uncomfortable Questions. IMF Working Paper WP/14/46

Conner, G. (2001), Lean Manufacturing for the Small Shop, Society of Manufacturing Engineers. (SME), Dearborn, MI.

Dalkey N and Helmer O. (1963), "An Experimental Application of the DELPHI Method to the Use of Experts". Management Science, Vol3, pp.458-467

Damrath, F. (2012) 'Increasing competitiveness of service companies: developing conceptual models for implementing Lean Management in service companies' Politecnico di Milano

DE VOS, A.S. (2005). Qualitative data analysis and interpretation. In De Vos, A.S., Strydom, H., Fouché. Pretoria: Van Schaik Publishers: 333-349.

Delgado, C., Ferreira, M., Branco, M.C. (2010) The Implementation of Lean Six Sigma in Financial Services Organizations. Journal of Manufacturing Technology Management, 21(4), 512-523.

Demoulin, N. T. M, and Djelassi, S. (2013) "Customer responses to waits for online banking service delivery", International Journal of Retail \& Distribution Management, Vol. 41 Issue: 6 , pp.442-460

Doffing, M. (2012) 'Streamlining operations can help banks add value', North Western Financial Review.

Domingo, R. T., (2015), Identifying and Eliminating The Seven Wastes or Muda, Asian Institute of Management

Doolen, T.L. and Hacker, M. E. (2005). A Review of Lean Assessment in Organizations: An Exploratory Study of Lean Practices by Electronics Manufacturers. International Journal of Manufacturing Systems. 24(1), pp. 55-67.

El-Namrouty, K. A. and AbuShaaban, M. S. (2013) 'Seven wastes elimination targeted by lean manufacturing case study: Gaza strip manufacturing firms', International Journal of Economics, Finance and Management Sciences, 1(2), pp. 68-80.

Emiliani, M.L (2004) "Improving business school courses by applying lean principles and practices", Quality Assurance in Education, Vol. 12 Issue: 4, pp.175-187,

Engelke, H., Mauksch, S., Darkow, I., \& von der Gracht, H. (2016). Heading toward a more social future? Scenarios for social enterprises in Germany. Business and Society, 55(1), 5689.

Esain, A. (2000) Networks, Benchmarking and Development of the Strategic Supply Base: A Case Study, International Journal of Logistics: Research and Applications, 3(2) European Union (2013) 'The Urban and Regional Dimension of the Crisis: Eighth Report on Economic, Social and territorial Cohesion'. Brussels, 5-8 September. Brussels: Publications Office.

Esain, A., Griffiths, D, and Hines, P. (2001) 'Performance Evaluation in the DVLA' in: (Ed) Erridge, A., Ruth, F. and McIlroy, J. (2001) Best Practice Procurement: Public and Private Sector Perspectives, Hampshire: Gower Publishing Limited.

Esain, A., Williams, S., Massey, L. (2010) Combining Planned and Emergent Change in a Healthcare Lean Transformation. Public Money \& Management, 28(1), 21-26. 
Flinchbaugh, J. (2001) "Beyond lean: building sustainable business and people success through new ways of thinking", Center for Quality of Management Journal, vol 10, No 2, pp. $37-50$

Gary J.E, von der Gracht H. (2015), The Future of Foresight Professionals: results from a global Delphi study", Futures, Vol 71, pp. 132-145.

Gopinath, S, \& Freiheit, T 2012, 'A waste relationship model and center point tracking metric for lean manufacturing systems', IIE Transactions, 44, 2, pp. 136-154, Business Source

Goriwondo, W. M., Mhlanga, S. and Marecha, A. (2011) 'Use of the Value Stream Mapping Tool for Waste Reduction in Manufacturing. Case Study for Bread Manufacturing in Zimbabwe', International Conference on Industrial Engineering and Operations Management,

Hallam, C., and Contreras, C. (2016) "Integrating lean and green management", Management Decision, Vol. 54 Issue: 9, pp.2157-2187

Haque, B. and James-Moore, M. (2004). Applying lean thinking to new product introduction. Journal of Engineering Design, 15 (1), pp. 1-31.

Harer J.B. (2003), "Performance Measures of Quality for Academic Libraries Implementing Continuous Improvement Projects: A Delphi Study", Advances in Library Administration and Organization, Vol 20, pp. 229-296.

HBA (2000), ‘e-banking: New Horizons for the Corporate Banking', Hellenic Banks Association.

Huang, S., Wu M., and Chen, L. (2013), "Critical Success Factors in Aligning IT and Business Objectives: A Delphi Study". Total Quality Management, Vol 24 No 10, pp. 12191240.

Hui, M.K. and Tse, D.K. (1996), "What to tell consumers in waits of different lengths: an integrative model of service evaluation", Journal of Marketing, Vol. 60, pp. 81-90.

Idrus, A.B., and Newman, J.B. (2002), "Construction Related Factors Influencing the Choice of Concrete Floor Systems". Construction Management and Economics, Vol 20, pp. 13-19.

Islam, D.M Z.; Meier, J.F.; Aditjandra, P.T.; Zunder, T.H.; Pace, G. (2012) "Logistics and Supply Chain Management." Research in Transport Economics, vol 41, Iss 1, pp. 3-16.

Jasti, N, \& Kodali, R 2015, 'Lean production: literature review and trends', International Journal of Production Research, 53, 3, pp. 867-885

Jimmerson C, Weber D, Sobek DK 2nd. Reducing waste and errors: piloting lean principles at Intermountain Healthcare. Jt Comm J Qual Patient Saf. 2005;31(5):249-257.

Johnston, R. (2008) 'Internal Service - Barriers, Flows and Assessment', 19(2), International Journal of Service Industry Management

Kouretas, G.P. and Vlamis, P. (2010) 'The Greek Crises: Causes and Implications.' Panoeconomics, 57: pp. 391-404

Julien, D.M. and Tjahjono, B. (2009), "Lean thinking implementation at a safari park", Business Process Management Journal, Vol. 15 No. 3, pp. 321-335.

Kaplan, GS 2012, 'Waste Not: The Management Imperative for Healthcare', Journal of Healthcare Management, 57, 3, pp. 160-166, Business Source Complete, EBSCOhost, viewed 24 November 2017. 
Katz, K.L., Larson, B. and Larson, R. C. (1991). 'Prescription for the waiting in line blues: entertain, enlighten and engage.' Sloan Management Review, Vol. 2, No. 4, pp. 320-39

Kell M, Tiwana A. and Bush A. (2002), "Reconciling User and Project Manager Perceptions of IT Project Risk: A Delphi Study”, Information Systems Journal, pp.103-119.

Knutson B.J., Beck J.A., Singh A.J., Kasavana M.L, and Cichy R.F. (2004), "Marketing to Lodging, Food Service and Club Consumers in the Future: A Delphi Study to Predict Marketing Management in 2007”, Advances in Hospitality and Leisure, Vol 1, pp. 25-41.

Kobayashi, I. (1995), Twenty Keys to Workplace Improvement, Productivity Press, Cambridge, MA.

Koskiala S., and Huhtanen A. (1989), "The Finnish Delphi Study: Forecasting the Extent of Information Technology Use in Libraries in 1996 and 2010”, The Electronic Library, Vol 7 No 3, pp. 170-175.

Kosow H., and Gassner R. (2008), "Methods of Future and Scenario Analysis Overview, Assessment, and Selection Criteria", Studies 39. German Development Institute: Bonn.

Larreche J., and Montgomery DB. (1977), “A Framework for the Comparison of Marketing Models: A Delphi Study”, Journal of Marketing Research, Vol 14, pp. 487-498.

Leyer, M., Moormann, J. (2015) How Lean are Financial Services Companies Really? Empirical evidence from a large scale study in Germany. International Journal of Operations \& Production Management, 34(11), 1366-1388.

Liker, J. (2004) The Toyota Way. New York: McGraw-Hill.

Linstone H, A., and Turoff M. (1975), "Introduction”. In H. A. Linstone, \& M. Turoff (Eds.). The Delphi method: Techniques and applications (pp. 3-12). Addison-Wesley Publishing Company: Reading, MA.

Liu, S., Zhang, J., Kell, M., and Chen T. (2010), "Comparing Senior Executive and Project Manager Perceptions of IT Project Risk: A Chinese Delphi Study", Information Systems Journal, Vol 20, pp. 319-355.

Lummus R.R., Vokurka R.J., and Duclos L, K. (2005), "Delphi Study on Supply Chain Flexibility”, International Journal of Production Research, Vol 43 No 13, pp. 2687-2708.

Makkonen, M., Hujala, T., and Uusivuori, J. (2016), "Policy Experts' Propensity to Change their Opinion Along Delphi Round", Technological Forecasting and Social Change, Vol 109, pp. 61-68.

Manalo, M.V. (2013), "Teaching Strategies for Business Ethics Courses in the Undergraduate Accountancy Curriculum”. DLSU Business and Economics Review, Vol 22 No 2, pp 82-94.

Mangan, J., Lalwani, C., \& Butcher, C. T. (2012). Global logistics and supply chain

Management. Wiley Higher Education

Mason-Jones, R., Naylor, B. and Towill, D.R. (2000), "Lean, agile or leagile? Matching your supply chain to the marketplace", International Journal of Production Research, Vol. 38 No. 17, pp. 4061-4070.

McCann, L., Hassard, J.S., Granter, E. (2015) Human Relations, 68(10), 1557-1577.

McCurry, L. and McIvor, L. (2001), “Agile manufacturing: 21st century strategy for manufacturing on the periphery?", Conference Proceedings, Irish Academy of Management Conference, University of Ulster, Ulster. 
McIntosh, B., Sheppy, B., Cohen, I. (2014) Illusion or Delusion - lean management in the health sector. International Journal of Health Care Quality Assurance. 27(6), 482-492.

Melnyk, S.A. Lummus, R.R., Vokurka, R.J., Burns, L.J. and Sandor, J. (2009) 'Mapping the future of supply chain management: a Delphi study', International Journal of Production Research, 47(16)

Miller, J., Wroblewski, M. and Villafuerte, J. (2013) Creating a Kaizen culture: Align the organization, achieve breakthrough results, and sustain the gains. United States: McGrawHill Professional.

Mitchell V. (1992), "Using Delphi to Forecast in New Technology Industries", Marketing Intelligence \& Planning, Vol 10 No 2, pp. 4-9.

Muller, H. (1997), "Long-haul tourism 2005 - Delphi study", The Tourist Review, Vol 52 No 3.pp.27-31.

Ndaita, P.M., Gachie, T., Kiveu, C.W. (2015) The Implementation of Lean Six Sigma Concept at National Bank of Kenya - Operation Division. The TQM Journal, 27(6), 683-690.

Neumann, W. P., and L. Medbo. 2010. "Ergonomic and Technical Aspects in the Redesign of Material Supply Systems: Big Boxes Vs. Narrow Bins.” International Journal of Industrial Ergonomics 40 (5): 541-548.

Okoli, C., and Pawlowski, S,D. (2004), "The Delphi Method as a Research Tool: an example, design considerations and applications". Information and Management, Vol. 42 No 1, pp. 1529.

Ohno, T. (1988) 'Toyota Production System: Beyond Large Scale Production', Productivity Press.

Okpala, C. C "Tackling Muda - The Inherent Wastes in Manufacturing Processes”.

International Journal of Advanced Engineering Technology, Vol.5, No. 4, pp. 6-11, 2014

Ortiz, C 2009, 'Lean and Time', Paperboard Packaging, 94, 7, pp. 10-11

Paliwoda S.J. (1983), "Predicting the Future Using Delphi”, Management Decision, Vol 21 No 1, pp. 31-38.

Papavasilieou, E.F. and Lyons, S.T. (2015). "A Comparative Analysis of the Work Values of Greece's 'Millenial' Generation”. International Journal of Human Resource Management, Vol 26 No 17, pp2166-2186.

Petry, K., Maes, B, and Vlaskam, C. (2007), "Operationalizing Quality of Life for People with Profound Multiple Disabilities: A Delphi Study", Journal of Intellectual Disability Research, Vol 51 No 5, pp. 334-349.

Pettersen J. Defining lean production: some conceptual and practical issues. The TQM Journal. 2009;21(2):127-142.

Piercy, N., Ruch, N. (2009) Lean Transformation in the Pure Service Environment: the case of the call service centre. International Journal of Operations \& Production Management. 29(1), 54-76.

Radnor, Z., Walley, P. (2010) Learning to Walk Before We Try to Run: adapting lean for the public sector. Public Money \& Management, 28(1), 13-20.

Ranchord, A. and Zhou, F. (2001). Comparing Respondents of Email and Mail Surveys: Understanding the Implications of Technology. Market Intelligence and Planning. 19(4). Pp. 254-262. 
Rashvand, P. and Majid, M.Z.A. (2014), "Critical Criteria on Client and Customer Satisfaction for the Issue for Performance Measurement. Journal of Management in Engineering, Vol 30 No 1, pp10-18.

Rawabdeh, I.A. (2005) 'A model for the assessment of waste in job shop environments', International Journal of Operations \& Production Management, 25(8), pp. 800-822

Ray, P. K. and Sahu, S. (1989) 'The Measurement and Evaluation of White Collar Productivity'. International Journal of Operations and Production Management, Vol. 9, Issue 4, pp. 28-47.

Ray P.K., and Sahu, S. (1990), "Productivity Management in India: A Delphi Study", International Journal of Operations \& Production Management, Vol 10 No 5, pp. 25-51.

Robson, C. (2002) Real World Research, $2^{\text {nd }}$ edn, Oxford: Blackwell

Rother, M., and J. Shook. 1999. Learning to See: Value Stream Mapping to Add Value and Eliminate Muda. Cambridge: Productivity Press.

Rowe, G., and Wright G. (1999), "The Delphi Technique as a Forecasting Tool: issues and analysis", International Journal of Forecasting, Vol 15 No 4, pp. 353-375.

Rupesh, K. M. and Narayanan, A.G.V. (2016). 'Store Choice: Understanding the Shopper's Preference in Selecting an Apparel Multi-Brand Outlet.' The IUP Journal of Marketing Management. Vol. XV, No. 1, pp. 36-48.

Russell, R.S. and Taylor, B.W., (1999), Operations Management. New York: Irving McGraw-Hill.

Sarkar, D. (2008) Lean for Service Organizations and Offices-Holistic Approach for Achieving Operational Excellence. ASQ Quality Press: USA

Sarkar, D (2010) 'Analysing the Value Contribution of Work for Process Improvement' Performance Improvement, vol 49, Iss 5, pp. 31- 34. May 2010

Schmidt , R. C. (1997) Managing Delphi Surveys using Nonparametric Statistical Techniques. Decision Sciences. 28, pp. 763-774.

Schmidt R., Lyytinen, K., Keil, M., and Cule, P. (2001), Identifying Software Project Risks: An International Delphi Study. Journal of Management Information Systems, Vol 17 No 4, pp. 5-36.

Scholl, W., Konig, C., Meyer, B., and Heisig, P. (2004), "The Future of Knowledge Management: An International Delphi Study", Journal of Knowledge Management, Vol 8 No 2, pp. 19-35.

Shang, S.S.C. (2012), "Dual Strategy for Managing User Resistancewith Business Integration Systems". Behaviour and Information Technology, Vol 31 No 9, pp 909-225.

Skulmoski G.J., Hartman, F, T., and Krahn, J. (2007), “The Delphi Method for Graduate Research", Journal of Information Technology Education, Vol 6 No 1, pp. 1-21.

Slack, N., Chambers, S. and Johnson, R. (2006). Operations management. $5^{\text {th }}$ edn. Harrow: Prentice-Hall.

Sohal, A. S. and Egglestone, A. (1994). 'Lean Production: Experience among Australian Organizations'. International Journal of Operations and Production Management. Vol 14, Issue 11, pp. 35-51.

Sowards, D 2017, 'How lean improves shop productivity', Contractor Magazine, 64, 8, p. 36 
Sullivan, W.G., McDonald, T.N. and van Aken, E.M. (2002),“Equipment replacement decisions and lean manufacturing", Robotics \& Computer-Integrated Manufacturing, Vol. 18 Nos 3/4, pp. 255-65

Svensson, G. (2001) "Just-in-time: the reincarnation of past theory and practice", Management Decision, Vol. 39 No. 10, pp. 866-79.

Syddell, M. (2005), “Going lean can mean plump profits”, Manufacturer's Monthly, March, pp. 19-20.

Taylor, S. (1994), "Waiting for service: the relationship between delays and evaluations of service", Journal of Marketing, Vol. 58, pp. 56-69.

Taylor, D. and Brunt, D. (2010) 'Manufacturing operations and supply chain management: the lean approach', Cengage Learning EMEA.

Tomas and Antonio (2006)

Varias, A.D. and Sofianopoulou, S. (2012) 'Efficiency evaluation of Greek commercial banks using DEA', 4(4), Journal of Applied Operational Research [Online].

Verstraete, C. (2004), "Planning for the unexpected", Manufacturing Engineer, Vol. 83 No. 3, pp. 18-21.

Watson, T. (2008), "Public Relations Research Priorities: A Delphi Study", Journal of Communication Management, Vol 12 No 2, pp. 104-123

Wentholt, M, T, A., and Frewer L, J. (2010), "Expert Views on European Research Needs Regarding Emerging Infectious Animal Diseases: Results of a Delphi Study", Coordination of European Research on Emerging and Major Infectious Diseases of Livestock. MCB Group: The Netherlands.

White, G.R.T. (2017) Future Applications of Blockchain in Business and Management: a Delphi study. Strategic Change, Special Issue on the Future of Money and Further Applications of Blockchain, 26(5), pp. 439-451.

White, G. R.T, and Cicmil, S. (2016) "Knowledge acquisition through process mapping:

Factors affecting the performance of work-based activity", International Journal of Productivity and Performance Management, Vol. 65 Issue: 3, pp.302-323,

White, G. R.T., and James, P. (2014) "Extension of process mapping to identify Green Waste', Benchmarking: An International Journal, Vol. 21 Issue: 5, pp.835-850,

White, G.R.T., Samuel, A., Jones, P., and Fisher, R. (2017) 'Social Enterprises Operating in the South Wales Valleys: A Delphi Study of Persistent Tensions. Social Enterprise Journal, Forthcoming

Wiggington, G, S, S. (1979), “Application of Delphi Techniques to Predicting Employee Relations Futures", Personnel Review, Vol 8 No 4, pp. 45-51.

Wojakowski, P. and Warżołek, D. (2017) "Work in Assembly Cell: A Case Study"

Research in Logistics and Production. Vol. 7, No. 1, pp. 41-51

Womack, J.P., Jones, D.T. and Roos, D. (1990) 'The Machine that Changed the World', Rawson Associates

Womack, J. P. and Jones, D. T. (1996). 'Beyond Toyota: how to root out waste and pursue perfection.' Harvard Business Review. September-October 1996 
Wong et al (2009)

Yin, R, K. (2013), “Case Study Research: Design and Methods”, SAGE, London.

Yong, Y, W., Keng, K, A., and Leng, T, L. (1988), “A Delphi Forecast for the Singapore

Tourism Industry: Future Scenario and Marketing Implications", International Marketing Review, Vol 6 No 3, pp. 35-46.

Yu-Lee, R.T. (2011). 'Proper Lean Accounting: Eliminating waste isn't enough; you have to reduce inputs to save money', Industrial Engineer: IE, 43, 10, pp. 39-43, Environment Complete, EBSCOhost, viewed 24 November 2017. 
Table 1: Waste Ranking from Various Industries

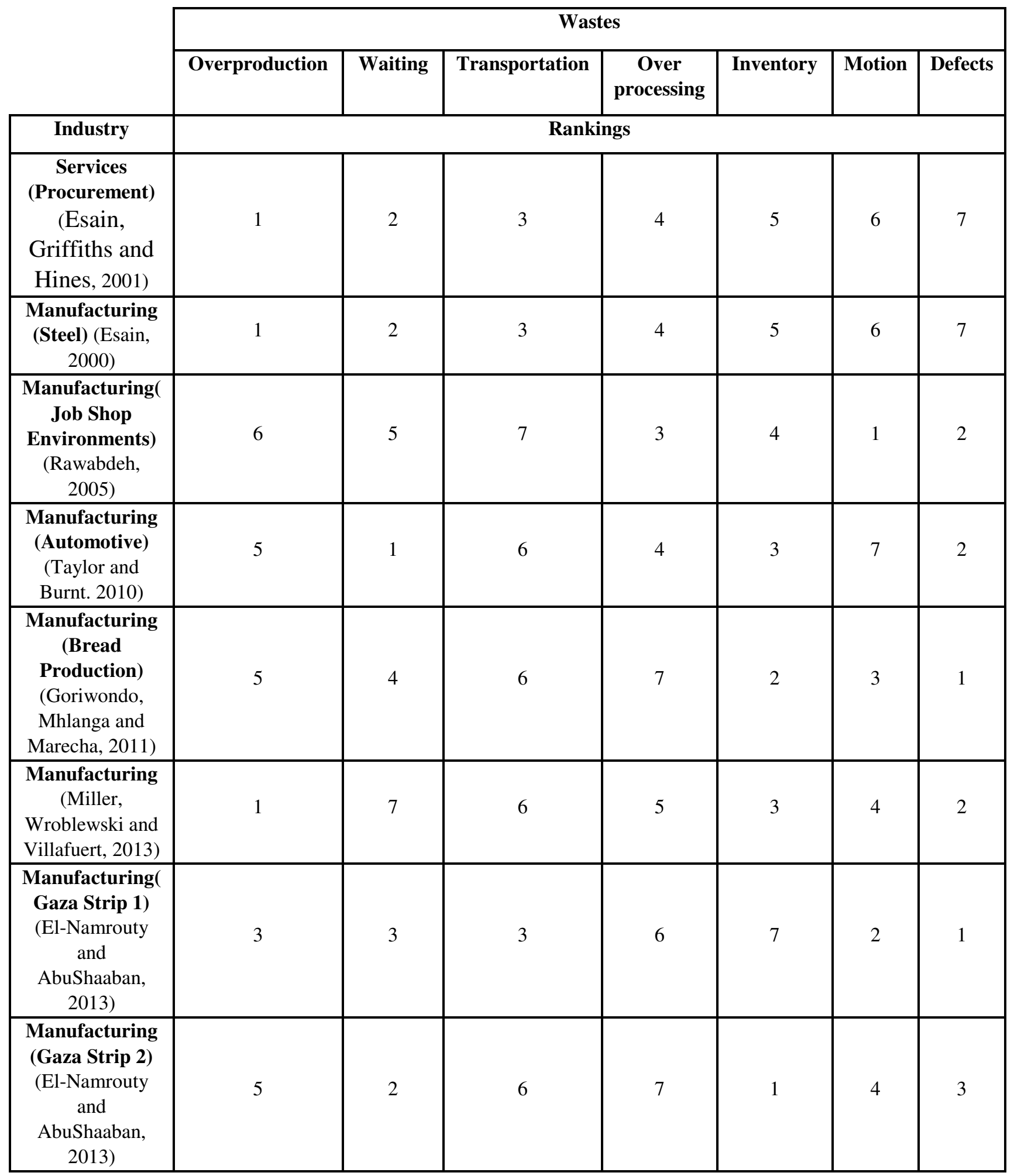


Table 2: Participant Demographics

\begin{tabular}{|l|c|c|c|}
\hline \multicolumn{1}{|c|}{ Participant } & Gender & Age & $\begin{array}{c}\text { Length of } \\
\text { Service }\end{array}$ \\
\hline Manager (M1) & M & 52 & 30 \\
\hline Manager (M2) & M & 44 & 19 \\
\hline Manager (M3) & M & 56 & 33 \\
\hline Manager (M4) & M & 43 & 17 \\
\hline Manager (M5) & M & 45 & 20 \\
\hline Manager (M6) & M & 55 & 30 \\
\hline Manager (M7) & M & 57 & 33 \\
\hline Manager (M8) & M & 37 & 12 \\
\hline Manager (M9) & M & 51 & 27 \\
\hline Manager (M10) & M & 56 & 32 \\
\hline Employee (E1) & F & 50 & 29 \\
\hline Employee (E2) & M & 42 & 15 \\
\hline Employee (E3) & M & 37 & 14 \\
\hline Employee (E4) & M & 60 & 34 \\
\hline Employee (E5) & F & 45 & 10 \\
\hline Employee (E6) & F & 48 & 23 \\
\hline Employee (E7) & F & 24 & 2 \\
\hline Employee (E8) & F & 46 & 19 \\
\hline Employee (E9) & M & 37 & 10 \\
\hline Employee (E10) & F & 45 & 22 \\
\hline
\end{tabular}


Table 3: Bank Demographics

\begin{tabular}{|c|c|c|c|l|}
\hline Bank & $\begin{array}{c}\text { Number of } \\
\text { Personnel }\end{array}$ & $\begin{array}{c}\text { Number of } \\
\text { Branches }\end{array}$ & \multicolumn{1}{|c|}{ Revenue } & \multicolumn{1}{|c|}{$\begin{array}{c}\text { Number of } \\
\text { Study } \\
\text { Participants }\end{array}$} \\
\hline "Beta" & 13,000 & $600+$ & 2.3 billion Eur & $\begin{array}{l}3 \text { Managers } \\
2 \text { Employees }\end{array}$ \\
\hline "Gamma" & 10,000 & $500+$ & 0.5 billion Eur & $\begin{array}{l}2 \text { Managers } \\
3 \text { Employees }\end{array}$ \\
\hline Delta" & 8,500 & $500+$ & 2.6 billion Eur & $\begin{array}{l}2 \text { Managers } \\
2 \text { Employees }\end{array}$ \\
\hline "Epsilon" & 8000 & $400+$ & 0.5 billion Eur & $\begin{array}{l}3 \text { Managers } \\
\text { 3 Employees }\end{array}$ \\
\hline
\end{tabular}


Table 4: Round 1 Rankings

\begin{tabular}{|l|c|c|c|}
\hline Waste & $\begin{array}{c}\text { Round 1 Employees } \\
\text { Rankings }\end{array}$ & $\begin{array}{c}\text { Round 1 Managers } \\
\text { Rankings }\end{array}$ & $\begin{array}{c}\text { Round 1 Overall } \\
\text { Rankings }\end{array}$ \\
\hline Overproduction & 5 & 1 & 3 \\
\hline Waiting & 4 & 3 & 2 \\
\hline Defects & 2 & 2 & 1 \\
\hline Motion & 6 & 4 & 5 \\
\hline Transportation & 7 & 7 & 7 \\
\hline Inventory & 1 & 5 & 6 \\
\hline Over-processing & 3 & 6 & 6 \\
\hline
\end{tabular}


Table 5: Round 2 Rankings

\begin{tabular}{|l|c|c|c|}
\hline Waste & $\begin{array}{c}\text { Round 2 Employees } \\
\text { Rankings }\end{array}$ & $\begin{array}{c}\text { Round 2 Managers } \\
\text { Rankings }\end{array}$ & $\begin{array}{c}\text { Round 2 Overall } \\
\text { Rankings }\end{array}$ \\
\hline Overproduction & 6 & 5 & 5 \\
\hline Waiting & 3 & 3 & 3 \\
\hline Defects & 2 & 1 & 2 \\
\hline Motion & 7 & 7 & 7 \\
\hline Transportation & 8 & 8 & 8 \\
\hline Inventory & 5 & 4 & 4 \\
\hline Over-processing & 4 & 6 & 5 \\
\hline $\begin{array}{l}\text { Underutilized } \\
\text { Resources }\end{array}$ & 1 & 2 & 1 \\
\hline
\end{tabular}

